\title{
ANALISIS KONSEP CIRCULAR AIRPORT UNTUK WILAYAH KEPULAUAN INDONESIA
}

\author{
Freddy Franciscus, Aprilia Sakti Kusumalestari* \\ Faculty of Aerospace Technology, Aerospace University of Air Marshal Suryadarma, Jakarta, \\ Indonesia \\ *corresponding author : freddyf60@rocketmail.com
}

\begin{abstract}
Abstrak. Konsep Circular Airport, yang dikemukakan oleh Hessellink pada tahun 2014, menimbulkan perdebatan dan perbedaan pendapat para ahli bandara. Sampai sekarang proyek ini masih berjalan. Tulisan ini membuat analisa awal tentang penerapan konsep circular airport di daerah Kepulauan Indonesia. Membangun bandara di area terbatas merupakan tantangan besar. Pengembangan beberapa rute perintis yang menghubungkan daerah-daerah terpencil dengan pesawat kecil terus dilakukan. Tantangan lain dalam membangun bandara adalah kelestarian lingkungan. Konsep circular airport diharapkan bisa menjadi solusi yang tepat untuk daerah Kepulauan Indonesia. Pembahasan mencakup analisa teknis dan safety terkait desain bandara, karakteristik pesawat terbang, Air Traffic Management $[$ ATM $\}$ dan juga analisa tentang lingkungan dan populasi daerah yang akan dikembangkan.
\end{abstract}

Kata Kunci : Konsep Circular Airport, rute perintis, daerah tertinggal, kelestarian lingkungan

\begin{abstract}
The Circular Airport Concept, issued by Hessellink in 2014, attracted the attention and differed opinions of airport experts. Until now this project is still ongoing. This paper makes a preliminary analysis of the application of the concept of a circular airport in the Indonesian Archipelago. Building an airport in a limited area is a big challenge. Development of several pioneering routes that connect the regions with small aircraft continues to be done. Another challenge in airport construction is environmental sustainability. The circular airport concept is expected to be the right solution for the Indonesian Archipelago. Discussion included technical and safety analysis related to airport design, aircraft characteristics, Air Traffic Management [ATM\} and also analysis of the environment and regional population to be developed.
\end{abstract}

Key Words: Circular Airport Concept, pioneer routes, disadvantaged areas, environmental sustainability

\section{PENDAHULUAN}

Konsep circular airport masih berkembang dan masih dalam perdebatan sejak kemunculannya kembali pada Tahun 2014. Konsepnya adalah tentang membuat circular runaway, dengan menekuknya menjadi bentuk lingkaran. Dengan diketahuinya kecepatan dan berat pesawat yang akan mendarat dan lepas landas, maka diameter lingkaran runaway dapat dihitung dengan pasti.

Latar belakang munculnya penelitian circular airport ini adalah dikarenakan adanya kesulitan operasion pesawat terbang menghadapi faktor cuaca saat pesawat terbang mendekati, mendarat, dan lepas landas. Alasan lainnya adalah terkait kelestarian lingkungan dan juga masalah populasi.

Tinjauan kepulauan Indonesia, ada banyak wilayah atau pulau-pulau kecil, konservasi tumbuhan dan hewan, dan konservasi budaya. Beberapa daerah diklasifikasikan sebagai daerah tertinggal, karena kesenjangan pembangunan daerah di Indonesia. Membangun bandara di sekitar area tersebut akan mendukung pertumbuhan ekonomi Indonesia. Cukup banyak rute dan bandara perintis di Indonesia yang menghubungkan antar bandara kecil di daerah terpencil. Namun demikian masih banyak daerah yang belum mempunyai bandara yang harus segera dibantu pengembangan bandaranya untuk 
memeratakan pembangunan di Indonesia sebagai negara kepulauan.

Menerapkan konsep circular airport di Indonesia akan menjadi ide baru yang tumbuh seiring dengan perkembangan konsep itu sendiri. Keunikan aspek geografi, demografi, dan lingkungan Indonesia akan membawa lebih banyak studi dan analisis. Tulisan ilmiah ini dapat menjadi bagian dari penelitian investigasi kelayakan membangun bandara di pulaupulau terpencil di Indonesia.

Tulisan ini pertama-tama akan membahas tentang konsep circular airport, kemudian menjelaskan tentang Indonesia berdasarkan faktor geografi, demografi, dan lingkungan. Pada bagian terakhir yaitu diskusi bagaimana menerapkan konsep circular airport.

\section{METODE PENELITIAN}

Dengan melakukan studi literatur untuk mengetahui dan memahami tentang konsep circular airport dan melakukan analisa awal pengembangan circular airport di daerah terpencil dan padat penduduk di Indonesia ditinjau dari aspek teknis, safety/keselamatan dan juga aspek lingkungan.

\section{PEMBAHASAN}

\subsection{Konsep Circular Airport}

Circular Airport merupakan konsep lama dari desain bandara, yang muncul dan hilang dengan berbagai alasan. Mengacu pada publikasi Paten Ameriaka Serikat, ada banyak desain circular airport yang telah dikeluarkan [1][2][3]. Seperti diilustrasikan pada Gambar 1, desainnya melingkar sempurna. Terminal ditempatkan di tengah runaway. Konsep ini dirujuk oleh Hesselink untuk merancang konsep baru dengan lebih modern, aktual, dan lebih terukur.

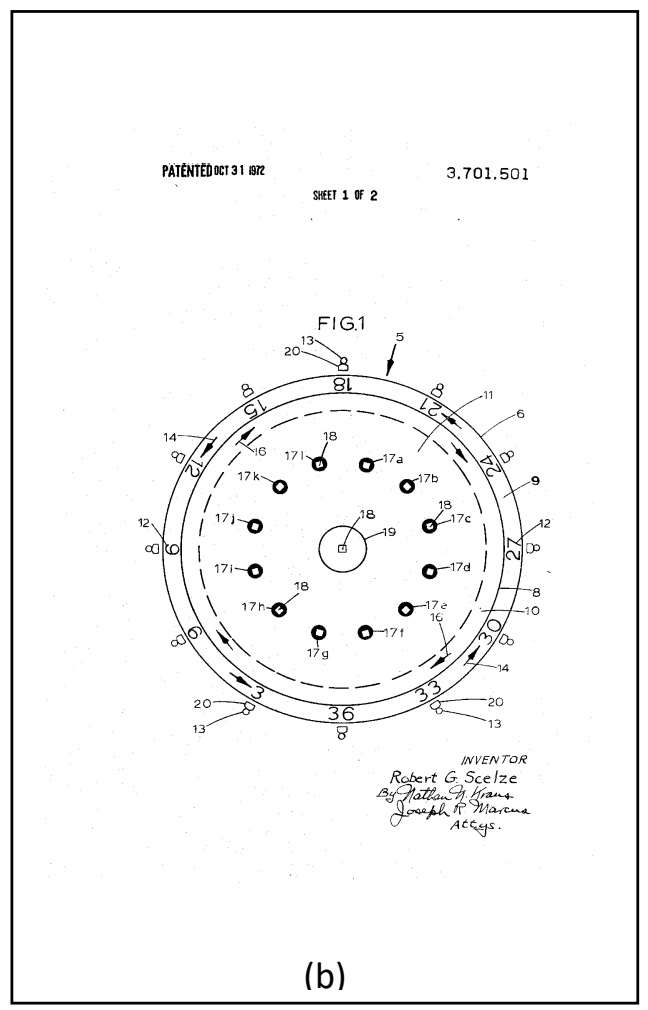

Gambar 1. Desain Airport oleh James S.Conrey, US Patent 3157374, Nov 1964 (a), dan Desain Dua Circular Runaway oleh Robert G. Scelze, US Patent 3701501, Oct 1972 (b) 
Dengan harapan dapat menyelesaikan banyak masalah bandara, konsep ini memiliki banyak tantangan terkait dengan aspek keselamatan dan keberlanjutan. Tetapi tantangan utama nya adalah untuk meningkatkan kapasitas bandara yang tersedia dengan mengoptimalkan penggunaan throughput sistem landasan yang ada dalam batas-batas keselamatan, emisi dan kebisingan. Konsep circular airport mempertimbangkan banyak faktor baik internal maupun eksternal. Faktor pertama adalah desain bandara itu sendiri, kedua karakteristik pesawat, dan ketiga prosedur manajemen lalu lintas udara (Air Traffic Management/ATM).

\subsubsection{Desain Bandara}

Faktor pertama mencakup perhitungan radius lingkaran, lebar runaway, dan sudut runaway bank. Untuk menghitung parameter tersebut, perancang dapat menggunakan rumus sederhana dari dinamika melingkar:

$$
F=\frac{m v^{2}}{R}
$$

di mana $F$ adalah gaya sentripetal, $m$ adalah massa tubuh, dan $\mathrm{v}$ adalah kecepatan linier.

Dalam penerapannya, perancang harus menghitung parameter gesekan, dan batasan massa dan dimensi pesawat. Dengan menggunakan rumus di atas, jarijari lingkaran bandara, lebar runaway, dan sudut kemiringan runaway dapat ditentukan.

Faktor-faktor lain dari desain bandara adalah tata letak taxiways, apron, lokasi menara kontrol, bangunan terminal, hanggar, area perawatan, bangunan pemadam kebakaran, dan akses ke bandara. Faktor-faktor ini dikelola dengan ketat dari sisi regulasi dan keamanan, dipadukan dengan arsitektur dan efisiensi.

\subsubsection{Karakteristik Pesawat}

Faktor kedua adalah karakteristik pesawat. Kenyamanan penumpang harus diperhitungkan dengan pertimbangan pendaratan melingkar. Parameter perhitungannya adalah kecepatan, sudut bank, parameter lepas landas dan pendaratan, roda pendaratan, engine, titik terbaik take-off dan landing, ground clearance, dan kewaspadaan situasional pilot.

Kecepatan dan sudut bank secara langsung mempengaruhi kenyamanan penumpang. Ketika penumpang merasakan $1 \mathrm{G}$ dalam posisi linier normal, sudut bank akan memberikan penambahan faktor G [4]. Untuk menentukan parameter lepas landas dan pendaratan, jenis pesawat harus diidentifikasi, sama pentingnya dengan spesifikasi landing gear dan mesin pesawat. Dan faktor terakhir dari karakteristik pesawat yang tak kalah pentingnya adalah kemampuan pilot.

\subsubsection{Prosedur ATM}

Topik ketiga adalah Prosedur ATM (Air Traffic Management). Topik ini mencakup operasi landasan, jalur dan rute (keberangkatan/kedatangan/kurva approach), penentuan titik lepas landas dan titik sentuh, prosedur mis approach, alat bantu navigasi, separasi yang diperlukan, kesadaran situasional dari pengontrol lalu lintas udara, penanganan kondisi meteorologi yang berbeda (angin kencang/angin sepoi), aspek lingkungan (polusi udara, kebisingan, risiko pihak ketiga).

\subsection{Kepulauan Indonesia}

Merujuk Kepulauan Indonesia, bagian ini akan meninjau negara dari aspek geografis, demografis, dan lingkungan. 


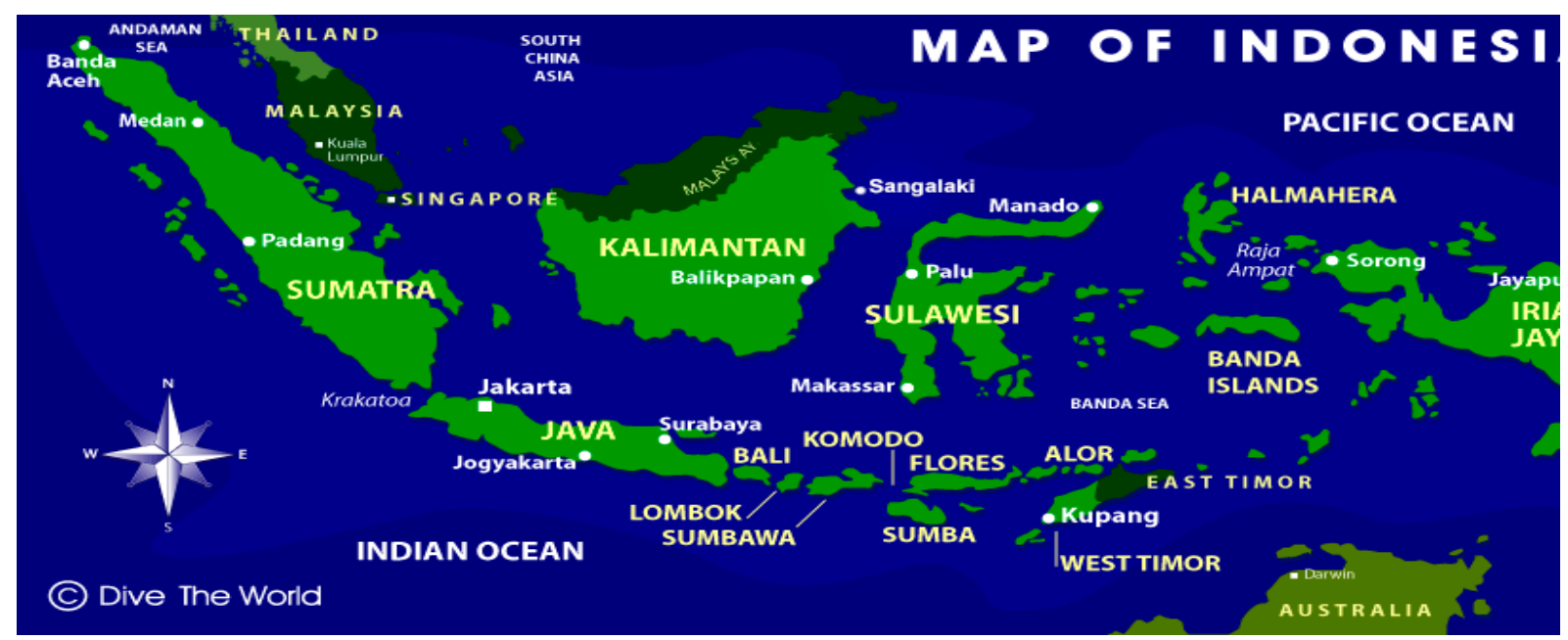

Gambar 2. Peta dari Kepulauan Indonesia

3.2.1. Wilayah Tertinggal dan Aspek Lingkungan di Indonesia

Melihat kondisi Indonesia, masih banyak daerah yang belum memenuhi standar pembangunan kawasan. Perhatian pemerintah Indonesia untuk menyamakan pembangunan dengan menugaskan Kementerian Pengembangan Daerah Tertinggal. Tujuan ini dapat dicapai dengan membangun fasilitas transportasi udara di area yang ekonomis, aman, dan memenuhi persyaratan. Di Indonesia, ada 34 provinsi, dan 23 provinsi di antaranya terdiri dari satu atau lebih kabupaten yang diklasifikasikan sebagai daerah tertinggal[5].

Beberapa daerah telah dijangkau oleh rute perintis. Baru-baru ini, diidentifikasi lebih dari 150 bandara perintis yang tersebar di seluruh kepulauan Indonesia. Sebagian besar berlokasi di Papua, dan lainnya tersebar di Sumatera, Sulawesi, Kalimantan, Nusa Tenggara, dan Maluku. Gagasan untuk mencapai standar pembangunan nasional, adalah bagaimana ibu kota provinsi dapat menjangkau seluruh wilayah wilayah terpencil di Indonesia. Untuk beberapa provinsi yang berbentuk pulau-pulau, masalah utama adalah transportasi. Menggunakan transportasi laut terbentur dengan kecepatan dan waktu. Pemanfaatan transportasi udara merupakan solusi yang paling tepat.

Selain daerah tertinggal dan rute perintis, ada banyak daerah konservasi hewan dan tumbuhan yang tersebar di seluruh Indonesia. Secara alami, konservasi membutuhkan lingkungan yang sunyi dan terpencil. Tetapi dalam beberapa kasus, daerah konservasi juga membutuhkan ketersediaan transportasi untuk mendukung pasokan obat-obatan dan mobilitas.

\subsubsection{Kepadatan Penduduk}

Beberapa bandara yang dibangun di Indonesia dikelilingi oleh populasi penduduk yang padat. Menurut studi tentang polusi udara, kebisingan, dan regulasi yang mengaturnya, maka di sekitar bandara tidak boleh padat penduduk dan tidak boleh banyak fasilitas pelayanan publik, seperti sekolah dan rumah sakit.

Di sisi lain, peradaban besar dengan mobilitas frekuensi tinggi membutuhkan ketersediaan transportasi pendukung, seperti stasiun bus dan bandara. Sementara itu membangun bandara baru di pusat kota tidak mungkin karena faktor kepadatan penduduk dan dampak lingkungan.

\subsection{Analisis Pengembangan Circular Airport}

3.3.1. Bandara Circular Mendukung Kemajuan Wilayah Tertinggal di Indonesia

Rute perintis untuk beberapa daerah tertinggal telah dibangun dan telah 
beroperasi. Sebagian dari bandara tersebut dioperasikan oleh militer Indonesia. Untuk membantu pemerintah dalam pengembangan bandara-bandara di daerah terpencil, maka studi untuk menerapkan circular airport di daerah terpencil di Indonesia harus sudah dimulai. Mengacu pada konsep circular runaway [6], penilaian aspek lingkungan harus sangat diperhatikan. Penilaian mencakup polusi udara dan mitigasi kebisingan. Membandingkan dengan bandara konvensional masih banyak perdebatan karena banyak faktor yang menjadi pertimbangan. Akan tetapi jika dilihat dari faktor resiko pada saat take-off dan landing maka konsep circular runaway adalah yang terbaik. Konsep tersebut dapat meminimalisir risiko kecelakaan yang disebabkan oleh side wind/angin samping.

\subsubsection{Bandara Circular untuk Populasi Padat}

Di Indonesia, populasi padat kadang tumbuh tak terkendali di sekitar bandara. Tidak hanya padat dengan perumahan umum, tetapi juga sekolah dan rumah sakit. Permasalahan kebisingan dan polusi udara dapat mengganggu ambang batas kenyamanan manusia. Circular airport di tengah kesibukan dan keramaian kota adalah lebih ramah lingkungan dibandingkan bandara konvensional [7]. Studi desain bandara bahkan menghasilkan ide untuk membangunan bandara di angkat tinggi dan didukung oleh pilar-pilar [8].

Untuk mendapatkan hasil optimal dari konsep circular airport ini, maka perlu dilakukan studi dan diskusi lebih lanjut untuk mendapatkan solusi optimal terhadap beberapa permasalahan di Kepulauan Indonesia. Saat ini konsep circular airport ditinjau dari sisi teknologi terasa seolah-olah lebih sulit dibandingkan teknologi saat ini. Akan tetapi dengan pesatnya perkembangan teknologi maka konsep tersebut memiliki kemungkinan menjadi lebih sederhana.

\section{KESIMPULAN}

1. Konsep circular airport adalah konsep airport yang tepat untuk dikembangkan di daerah tertinggal dan terpencil di kepulauan Indonesia untuk membantu pertumbuhan perekonomian di tanah air.

2. Faktor utama yang perlu diperhatikan dalam konsep ini selain masalah kelestarian lingkungan dan populasi juga adalah masalah yang terkait teknis dan safety pesawat terbang seperti keahlian pilot, air traffic management/ATM dan teknologi pesawat terbang terutama landing gear.

\section{DAFTAR PUSTAKA}

1. US Patent 3157374, Airport Design, James S. Conrey, Nov 1964

2. US Patent 3173634 , Closed Track Airport, A. Woldemar, March 1965

3. US Patent 3701501, Two Circular Runways, Robert G. Scelze, Oct 1972

4. Henk Hesselink, The Endless Runaway : Concept Description, Nationaal Lucht- en Ruimtevaartlaboratorium, The Netherland, 2012

5. Henk Hesselink, The Endless Runaway : State of The Art, Nationaal Lucht- en Ruimtevaartlaboratorium, The Netherland, 2014

6. Henk Hesselink, The Endless Runaway : Assessment, Nationaal Lucht- en Ruimtevaartlaboratorium, The Netherland, 2014

7. Peraturan Presiden Nomor 131 Tahun 2015 tentang Penetapan Daerah Tertinggal Tahun 2015 2019, November 2015

8. US Patent 5398635, Durando, A.R. and H.M. Weiss, Floating Airport, Filing date Nov. 18, 1993, Issue date Mar. 21, 1995

9. http://hubud.dephub.go.id/bandara/ 
